\title{
THE WENNERGREN INTERNATIONAL CENTRE FOR SCIENTIFIC RESEARCH
}

\begin{abstract}
$\mathrm{T}$ HE Swedish industrialist Dr. Axel WennerGren has recently announced a new donation for the benefit of science, to be administered by a new foundation ealled the WennerGren Centre for Scientific Research. Some of his earlier gifts for science are well known. In 1937 he founded the WennerGren Society in Stockholm and the Institute for Experimental Biology in the University of Stockholm. The Society has supported the Institute as well as many research activities in other fields. In 1941 he created in New York the Foundation for Anthropological Research, which has among other activities not less than five scientific expeditions in South and Central Africa studying the first traces of the early history of man. This Foundation also serves most successfully as a clearing centre for a large number of universities and specialists in the field of social and anthropological sciences. It may be mentioned that the discovery of the carbon-14 method for age-determination by Prof. W. F. Libby was the product of an investigation supported by this Foundation.

Dr. WennerGren's new donation may be considered as a first step for stimulating and supporting international co-operation in scientific research on a broader base. The members of the board of the new Foundation have just been announced. Chairman of this Foundation will be the Lord Chamberlain of Sweden, Birger Ekeberg, who is also chairman of the WennerGren Society and of the Nobel Foundation.
\end{abstract}

The first undertaking of the new Foundation will be a building to serve as the permanent seat for the central organization. The building also will haveand this is a very important point-accommodation for housing (at moderate costs) foreign scientists who are doing research work at one of the many research institutes in the Stockholm area. For this purpose, there will be furnished apartments and rooms for about a hundred scientists, restaurants, club-rooms, lecture halls, etc. It will also serve as a meeting centre for national and international symposia, as well as for smaller and informal gatherings for the promotion of personal contacts between scientists from different research fields.

It is expected that the Government of Sweden and the City Council of Stockholm, which have shown an active interest in the plans, will provide a suitable, centrally located site for the building. According to the present plans, the new building will be ready for occupation in about two years.

From the communication in which Dr. WennerGren announced his new donation, the following words may be cited: "For a long time I have personally been convinced that many of the great problems of mankind can have a satisfactory solution only on a scientific basis. That is the reason why I have tried to support both pure and applied research for many years and I have now decided to make available-one could say by instalments-nay re. sources for the furthering of such activities".

\section{OBITUARIES}

\section{Dr. W. G. Shilling}

Dr. W. G. Shilcing, head of the Materials Division of the Aeronautical Inspection Directorate, Ministry of Supply, died suddenly on October 16.

William George Shilling was born at Faversham, Kent, on February 21, 1899. During 1910-16 he attended the Henry Wreight School, now the Faversham Grammar School, where he passed the Inter.B.Sc. (London) Examination. He joined the Army at the age of seventeen, was commissioned and was awarded the Military Cross in 1918. His rank on demobilization in 1919 was staff major.

Shilling spent the next eight years at East London (now Queen Mary) College, University of London. He graduated B.Sc. (honours in chemistry) in 1921 and then began research on the specific heat of gases under the direction of Prof. J. R. Partington. After making very accurate determinations at ordinary temperatures, he extended the method, which involved measuring the velocity of sound, to higher temperatures up to $1,800^{\circ} \mathrm{C}$. Shilling was a most ingenious and skilful manipulator, expert in devising and perfecting apparatus. He also collaborated with Prof. Partington in writing a book, "The Specific Heat of Gases", a classic in this field. Shilling was awarded the M.Sc. in 1922 and D.Sc. in 1927.

During 1927-43 Shilling was in charge of chemical and physical research for the International Paint and Compositions Co., Ltd., Newcastle upon Tyne. His main work was on ships' under-water paints, but he also dealt with all other types of protective and decorative finishes. During this time he played a leading part in the local civil defence organization.

In 1943 Shilling joined the Aeronautical Inspection Directorate as the assistant director in charge of the non-metallic materials branch, becoming head of the Materials Division in 1947. For some years he was also responsible for the technical direction of the A.I.D. Laboratories at Harefield, being especially concerned with the development of new methods of inspecting and testing the wide range of materials and equipment used in Service aircraft and ground installations.

Throughout his life, Shilling retained his manual dexterity, and he was interested in clock making and the construction of electronic apparatus. He kept his love of the countryside and was never happier than when working on his estate; he was a loyal member of his Church and a keen Mason. His modesty, good nature and integrity won Shilling a host of friends in many walks of life, who mourn his untimely death. He is survived by his widow and two daughters, whose consolation will remain that his happy home was the centre of his life.

H. J. CuRnow 